\title{
咬合治療の効果と咬合音診断
}

\author{
本 間 修 平 \\ 新潟大学歯学部歯科保存学第 2 教室 \\ （主任・指導 : 原 耕二教授） \\ (昭和 59 年 9 月 19 日受付)
}

\section{Treatment Effect of Pocket Elimination and Coronal Reshaping \\ by Recording the Sounds of Tooth Impact}

\author{
Shuhei HONMA \\ Department of Periodontology, Niigata University School of Dentistry \\ (Chief and Director : Prof. Kohji HARA)
}

\begin{abstract}
A case in point is the procedure in diagnosis by visualization of occlusal tones. This procedure is designed to record occlusal tones in wave patterns, using systems devised by the author, in order to grasp quantitatively the wave patterns and the duration of occlusal contacts.
\end{abstract} articulating paper depends, in a large measure, on the technical level and experience of those in the dental profession.

The procedure in diagnosis developed by the author is hopefully expected to have overcome such a shortcoming.

It is said that diagnosis by use of the conventional

Key words : Occlusal tones, Normal occlusion, Occlusal trauma, Occlusal adjustment

要旨 : 本研究は, 咬合性外傷を有する歯周炎罹患者に対して, 歯周ポケット除去, 咬合調整を含む初期治療を行な い, その効果を評価する方法として, 臨床的診査のほか咬合音診査として波形の形態, 咬合音持続時間 (duration) を測定し，その変化について検討した。

Base line となる正常咬合者 11 名に対しては至適な咬合接触を得るための咬合調整を行ない，また歯周炎罹患者 10 名には上記の初期治療を行ない，これら処置前後に咬合音波形を測定し，経時的変化を調べた。

その結果, 正常咬合者の咬合音波形は, 殆んどの症例において咬合調整の有無にかかわらず，impact 型で duration は $10 \mathrm{msec}$ 以下と短かった。歯周炎罹患者の咬合音波形は初期治療前, slide 型で長い duration であったも のが治療後, ポケットの梁さ, 歯の動摇度の減少など歯周組織の改善に伴い正常咬合者の波形形態及び duration に 近づいた。

索引用語 : 咬合音, 正常咬合, 咬合性外傷, 咬合調整

\section{緒言}

既に存在する歯周炎に，外傷性咬合のような異常な咬

本論文の要旨は, 昭和 58 年 11 月第 15 回日本歯科医学会総 会, 第 71 回 FDI 年次世界歯学大会及び昭和 59 年 4 月第 17 回 新潟歯学会総会に於いて発表した。
合がかかわりをもつと，歯周組織は速やかに破壊するこ と 1 4)を臨床上，しばしば遭遇する。このような場 合， 術者は経験に基づいて, 咬合性外傷罹患歯と対合歯との 接触関係を診查し, 必要に応じて咬合調整を行い, 至適 な接触関係に改善する ${ }^{5 \sim 8)}$ 。

咬合を診查する場合, 従来から一般的に行われている 咬合紙などを使用する印記法では, 咬合異常の時間的要 


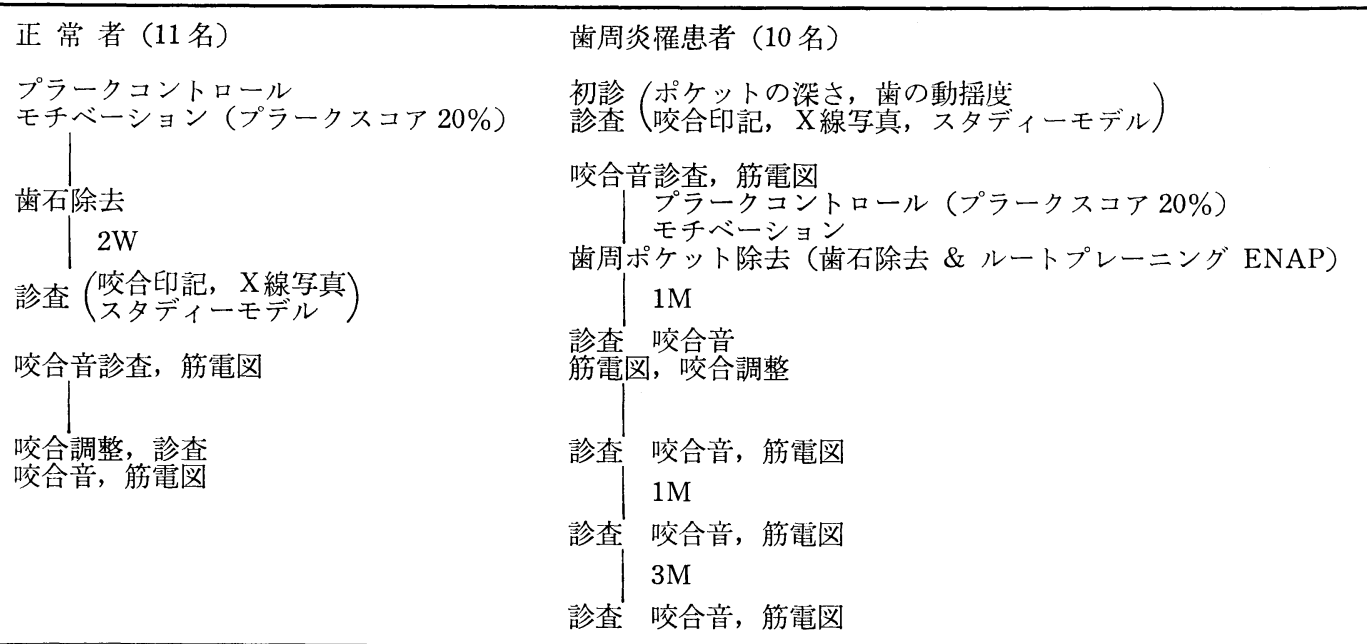

素が含まれていないことや，さらに上下頡の咬合歯間に 物を介在させて接触を認知するので真の印記か，または 污れかを識別することが難しく何よりも術者の熟達さが 要求され，診查の的確性に欠く恐れがあると考えられ $ろ^{9,10)}$ 。

近年, $\mathrm{ME}$ 機器の開発が盛んになる中で, 広く歯科臨 床分野においても，ME 機器を利用し，咬合音を視覚で とらえて咬合の診査，診断に役立たせようとする試みが 推奨されるようになってきた ${ }^{11)}$ 。

そこで本研究は，う蝕がなく歯冠修復並びに補緅処置 のなされてない天然歯 28 歯がすべて揃った正常咬合者 及び咬合性外傷を伴う歯周炎䍜患者を対象とし，咬合調 整の効果が，咬合音並びに臨床症状にどのような変化を もたらすのかを検討した。

\section{研究材料と方法}

\section{1. 被検者の選択}

正常咬合者は，う蝕がなく，処置されていない28歯 がすべて揃っており，かつ臨床的㧍よびX線学的に健康 な歯周組織と正常な歯列を有する 11 名を 700 名の中か ら抽出した。その構成は, 年齢 16 歳 2 21 歳, 男性 6 名, 女性 5 名であった。

\section{2. 実験のプロトコール}

実験の前処置のステップを表 1 に示す。正常咬合者 11 名に関しては, 初診時, モチベーションとブラッシング を主体としたプラークコントロールの指導と, その励行
を約束した後, 全䫟にわたる歯肉縁上の歯石除去を行っ た。ついで 10 日〜14 日後に来院させ，まずブラッシン グのチェックを行い，次に咬合印記による咬合診査，咬 合音診断機器による咬合音診査を行った。ついで全䫑に わたり歯冠の形態修復 ${ }^{5} 8$ ( (以後咬合調整とよぶ)を行っ た。この段階で被検者全員が咬頭嵌合位で至適な咬合接 触をとることを再び咬合印記による咬合診査と咬合音の 診査を行って確認した。歯冠の形態修復法に関しては, 教室の中島 ${ }^{5,7)}$, 佐藤ら ${ }^{13)}$ がすでに報告したとお りであ る。

一方, 歯周炎罹患者は, 新潟大学歯学部附属病院保存 科外来に来院した患者から咬合性外傷を有する歯周炎罹 患者 10 名を選んだ。歯周炎の程 度は, 歯周ポケットの 深さ, 歯の動摇度, 歯槽骨の吸收率 (X線学的診査) 加 ら 10 名中 4 名が軽度で, 5 名は中等度, 残り 1 名が高度 な歯周炎と診断された。10名の歯周炎罹患者全員は初 診時に, 歯周ポケットの梁さ, 歯の動摇度の測定, 及び $\mathrm{X}$ 線写真，診断用石高模型（スタディーモデル）の印象 など，診断用資料の準備と，咬合印記及び，咬合音によ る咬合診查, さらに咀嚼筋筋電図診査をあわせて行っ た。これら診査の終了後, 歯周炎罹患者に対しては, 特 に歯周炎に対するモチベーションにビデオ，及びスライ ドなどの視聴覚機器15)を使用し，ブラッシングを主体と したプラークコントロールの指導と励行を徹底させた。 次回の来院時に MT-1000 の歯垢染 出し 液 ${ }^{16)}$ にて O'Leary plaque score ${ }^{17)}$ を算出し, score が $20 \%$ 以下に なることを条件とした。次に，歯肉の炎症と歯周ポケッ 
トの除去法として, 全䪽にわたる歯石除去と一部は ENAP $^{18)}$ (Excisional New Attachment Procedure) を 含むルートプレーニング（root planing）を徹底的に行 った。治癒期間として約 1 力月経過後, 全顎にわたり, 咬合調整を行った。なお，歯周組織の診査，咬合接触診 査 (咬合印記), 咬合音診查, 筋電図診查は, 基本的な診 查として初診時, 咬合調整值前, 咬合調整直後, 咬合調 整 1 力月後と 3 力月後にそれぞれ実施した。診查後, 至 適な咬合接触を得ていない事例を確認した時は，その都 度，咬合調整を行い，修正した。また，正常咬合者，歯 周炎罹患者ともに, 実験期間を通してプラークスコアが 常に $20 \%$ 以下になるようプラークコントロールをチェ ックしながら実験を進めた。

\section{3. 咬合音診断機器}

咬合音の分析法に関して，著者は咬合音波形の分類及 び持続時間（duration）の測定を採用した。咬合音波形

表 2 咬合音診断用機器と附属機器

$\begin{array}{cc}\text { デンタルサウンドチェッカー } & \mathrm{TME} 202 \mathrm{C} \\ \text { サンプリングタイム } & 5 \mathrm{msec} / \mathrm{cm} \\ \text { AHEAD MODE } & 256 \\ \text { MAGNIFIER } & \times 1 \\ \text { ハイパスフィルタ } & 350 \mathrm{~Hz} \\ \text { コントローラ } & \\ \text { ペンレコーダ } & \text { REC } 202 \\ \text { RANGE } & \\ \text { CHART SPEED } & 150 \mathrm{~mm} / \mathrm{min}\end{array}$

ポラロイドカメラ M-085

$\begin{array}{ll}\text { シャッタースピード } & 1 / 2 \mathrm{sec} \\ \text { 絞 } リ & 5.8\end{array}$

FILM 白黒 TYPE667
の分類及び duration 測定はデンタルサウンドチェッカ 一TME 202 C 型 ( $ヨ$ シダ社製) を使用した（表2)。そ の附属機器として X-Y ペンレコーダ REC-202,ハイパ スフィルタコントローラ, 及びポラロイドカメラ M-085 を使用した。デンタルサウンドチェッカー TME $202 \mathrm{C}$ 型はサンプリングタイムを $5 \mathrm{msec}$, アヘッドモードを 256 , マグニファイヤーを×1にセットした。波形記録に 使用した X-Y ペンレコーダ REC-202 は, レンジを $20 \mathrm{~V}$, チャートスピード $150 \mathrm{~mm} / \mathrm{min}$ に合わせ操作し た。また, $350 \mathrm{~Hz}$ 以下の信号は H.P.F. (High Pass Filter, $\mathrm{fc}=0.35 \mathrm{kHz}$, 減衰特性 $40 \mathrm{~dB} /$ decade) でカット した。波形の記録はポラロイドカメラ M-085 (シャッタ ースピード : $1 / 2 \mathrm{sec}$, 絞り $: \mathrm{F}=5.8)$ とし, 白黒フィル ムTYPE 667 を使用した。図 1 に示したピックアップ マイクロフォンの周波数帯域は, $80 \mathrm{~Hz}-10 \mathrm{kHz}$ を有す るコンデンサマイクロフォンで, $-65 \mathrm{~dB}$ までの感度を 有する。増幅器はアイソレーション型のプリアンプとメ インアンプからなり，その帯域は， $50 \mathrm{~Hz} \sim 10 \mathrm{kHz}$ であ る。ここで増幅されたアナログ信号は, ハイパスフィル 夕 (H.P.F., fc $=0.35 \mathrm{kHz}$, 減衰特性 $40 \mathrm{~dB} /$ decade) で処 理する。次に, サンプリング周期 $25 \mu \mathrm{s}$, 分解能 8 bits を有する A/D 変換器で, アナログ信号をデジタル信号 に変換する。

ここで 1 byte は 8 bits であるから 256 の分解能があ る。さらに, このデジタル信号は $32 \mathrm{kbits}$ の RAM (Randam Access Memory) に記憶される。したがって, $1 \mathrm{ch}$ あたり 2,048 byte, $2 \mathrm{ch}$ では合計 4, 096 byte (=32 kbits) の信号を記憶できる。この RAM に記憶さ れたデジタル信号は, つづいて, 再生時の変換周期 250 nsec, 分解能 8 bit を有する $\mathrm{D} / \mathrm{A}$ 変換器でアナログ信 号となり, ディスプレイされる。

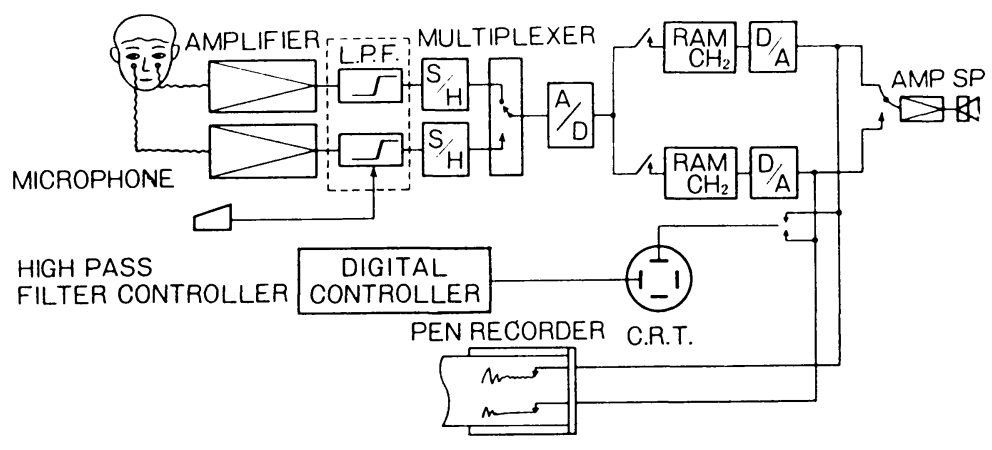

図 1 デンタルサウンドチェッカーの内部構造 


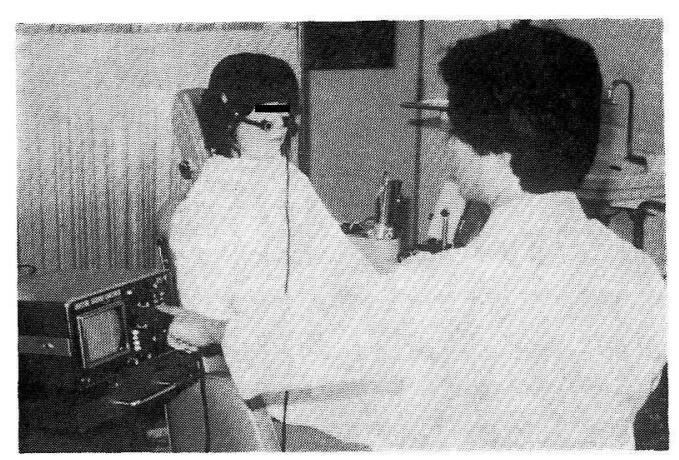

図 2 ヘッドギヤ型マイクロフォンの装着

\section{4. 咬合音波形のサンプリング}

サンプリングは, 一定の高さの振幅波形を得るために 咬頭嵌合位で約 20 回のタッピングの練習をさせた後, 10 回のタッピングを採用した。サンプリングする際, ヘッ ドギヤ型マイクロフォンの位置は左右眼下煩骨部に設定 した（図 2)。なお，周囲の雑音，例えば，エアータービ ンの回転音，超音波スケーラーなどの発生音，金属音， 話し声などの介入をできる限り避けた環境で測定した。 デンタルサウンドチェッカーに接続したペンレコーダ波 形を記憶し，同時にデンタルサウンドチェッカーの C.R.T. (Cathod Ray Tube) 上に写し出された波形を ポラロイドカメラで撮影した (図 3)。

\section{5. 筋電図の測定}

測定の際，被検者をそのカンペル氏平面と床が平行に なるように歯科用治療椅子に座らせたのち前方を正視さ せ，リラックスさせた。タッピング速度は，L.E.D. (Light Emitting Diode) 点滅のリングカウンターで 120 回/分に規定し, 最初の 5 回を除く 25 ストロークを分析 に用いた。

筋電図誘導部位は, 両側の咬筋中央部と側頭筋前腹と し, 中心間距離 $25 \mathrm{~mm}$ に固定した双極表面電極（日本 光電）を筋線維と平行に貼付した。同時に，右外耳道に

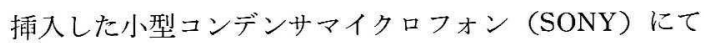
咬合接触の指標となる咬合音を記録した。筋電計は，平 衝入力型アイソレーションアンプ (日本光電, AB-600

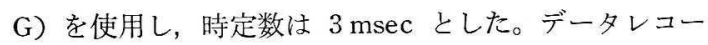
ダは, 4 スピード, 7 チャンネルカセット式データレコー ダ (TEAC, R-81), 記録されるデータモニターはストレ ージ型ブラウン管オシロスコープ (TEKTRONIX, 5113) および， 8 チャンネルブラウン管モニター（日本光電, VC-680 G) を用いた。筋電図分析用コンピュータシス テムは, $64 \mathrm{~kW}$ のメモりを持つミニコンピュータ（MEL

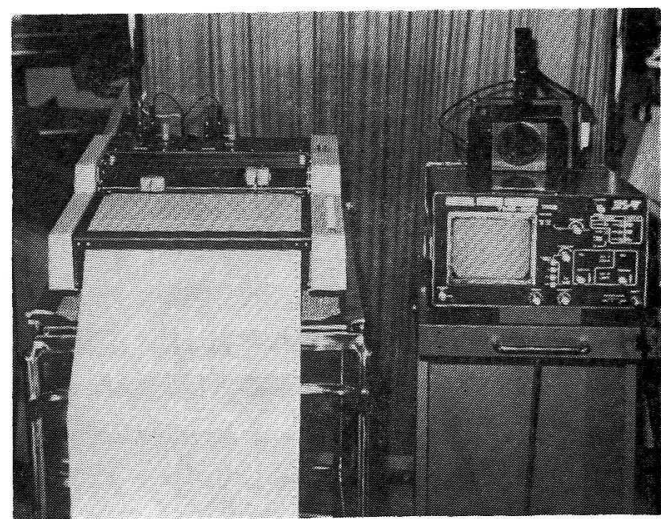

図 3 右: デンタルサウンドチェッカーとポラ ロイドカメラ

$$
\text { 在: X-Y ペンレコーダ }
$$

COM, 70/25）を使用した。

\section{結果}

\section{1. 正常咬合者}

\section{1）歯周組織と咬合診査}

正常咬合者 11 名は，すべて全顎にわたり $2 \mathrm{~mm}$ 以下 の歯肉溝を有し, X線学的にも歯根膜, 歯槽骨に何ら異 常がなかった (図 4)。咬合調整前の咬合印記は, 必ずし も原則にそった至適な接触 (8) を示さなかったが，咬合 調整によって全員を至適な咬合接触に修正した。

\section{2）咬合音診査}

正常咬合者 11 名の波形は咬合調整前後ともに impact 型波形が多くみられた (図 5)。11名中 1 名は咬合調整 前後の波形に大きな変化が生じた。すなわち咬合調整前 2 相性の波形が調整後 1 相性に変化した。また, 咬合音 波形の duration については, 図 6 に示す 11 名の平均值 と標準誤差をみると, 咬合調整前 $9.3 \pm 0.3 \mathrm{msec}(5.3 \sim$ $15.2 \mathrm{msec}$ ) であったものが咬合調整後に $8.4 \pm 0.2 \mathrm{msec}$ (6. 0 12. $5 \mathrm{msec)}$ と減少し, 雨者閒には有意差がみられ た $(\mathrm{p}<0.05)$ 。

\section{2. 歯周炎罹患者}

\section{1）歯周組織診查用パラメータの变化}

本実験における歯周組織診查用パラメータは，歯の動 摇度，歯周ポケット深さとした。

動摇度は次に述べる 3 段階指数に従って判定した。す なわち, 動摇 0 度 : 動摇が生理的範囲内でほとんど認め られない。動摇 1 度 : 唇舌的動摇のみを示すもの。動摇 2 度 : 唇舌的動摇に近遠心及び垂直的動摇が加わるも 


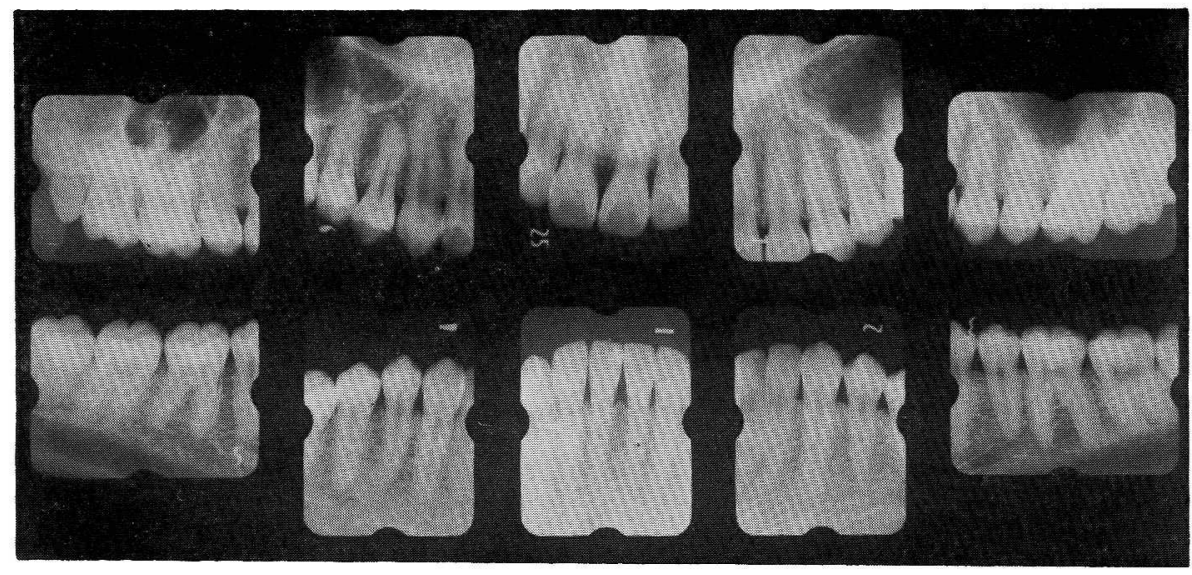

図 4 正常咬合者のX線像
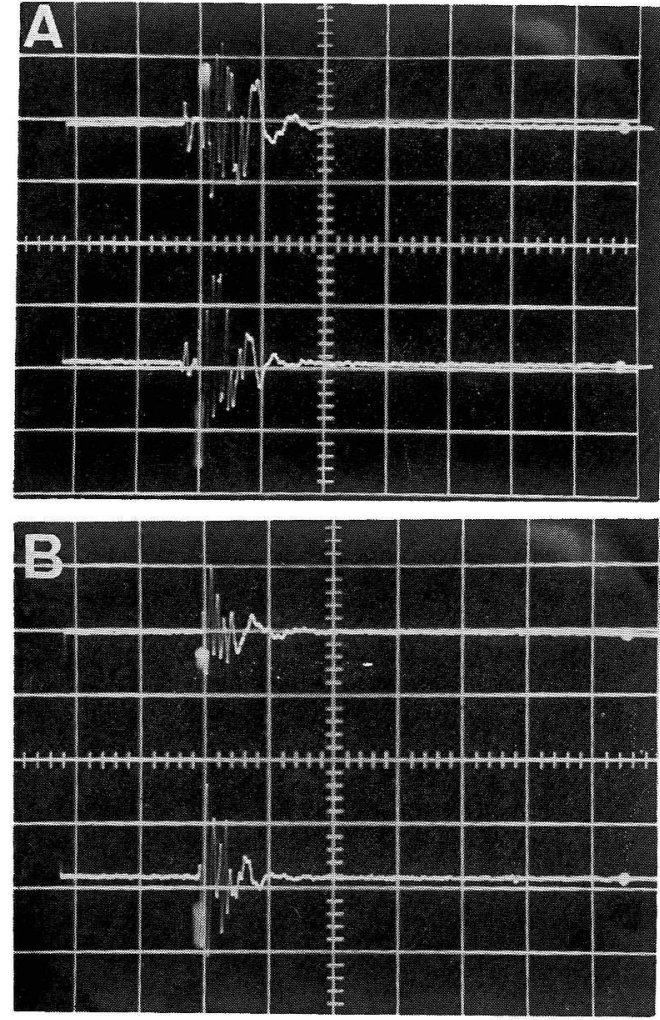

図 5 正常咬合者の波形
A：咬合調整前
$\mathrm{B} ：$ 咬合調整後

の。そこで，歯の動摇の変化を表すため，全顎にわたっ て動摇 1 度または 2 度を示す歯数の和を各時期で求め, $\mathrm{t}$-検定した。その結果の変動ヒストグラフを図 7 に示 す。表 3 は $\mathrm{t}$-検定表である。動摇歯数は初診時 (Ptr)

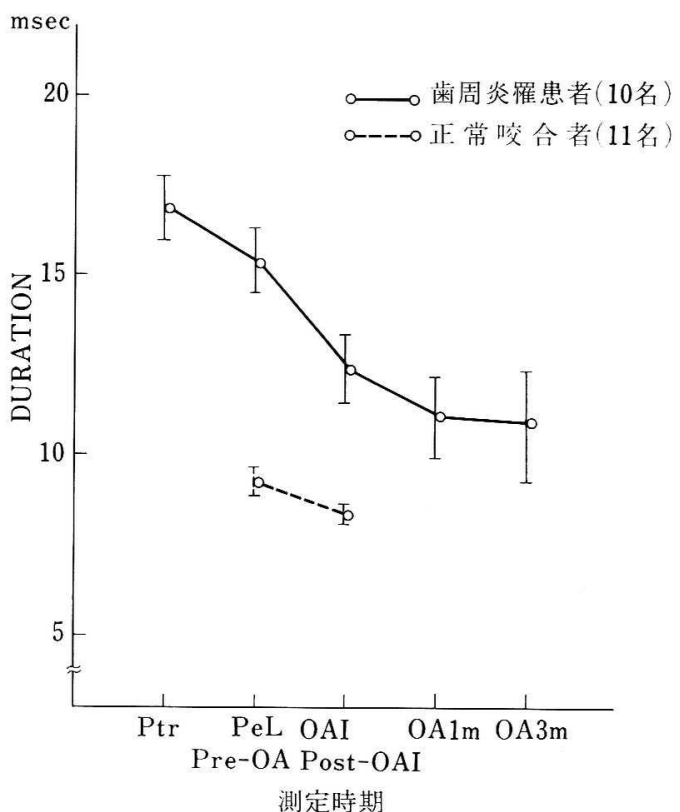

図 6 Duration の経時的変動

$\mathrm{Ptr}$ : 初診時, $\mathrm{PeL}$ : 歯周ポケット除去後 1 力月, OAI：咬合調整直後, OA1m：咬合調整後 1 力月, $\mathrm{OA} 3 \mathrm{~m}$ : 咬合調整後 3 力月

Pre-OA：咬合調整前, Post-OAI : 咬合調整直後

に対して咬合調整後 3 力月（OA $3 \mathrm{~m})$ になって有意な減 少が認められた（p<0.05）。

歯周ポケットの梁さは, $3 \mathrm{~mm}$ 以下, $4 \sim 6 \mathrm{~mm}, 7 \mathrm{~mm}$ 以上の 3 段階に分けて, 4〜 $6 \mathrm{~mm}, 7 \mathrm{~mm}$ 以上のポケット を示寸歯数の和を各時期で求め, $\mathrm{t}$ 一検定した。その変 動のヒストグラムを困 8 に示した。表 4 は $\mathrm{t}$-検定表で ある。歯周ポケットの哚さは初診時 (Ptr) に対して, 歯 


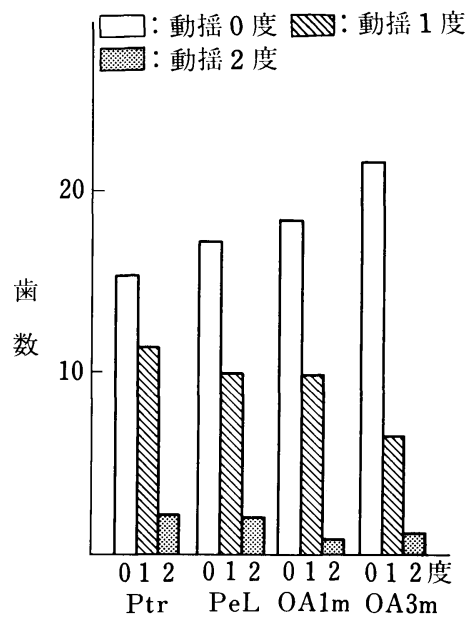

図 7 動摇歯数の経時的変動

Ptr, PeL, OA1m, OA3m は図 6 と同じ

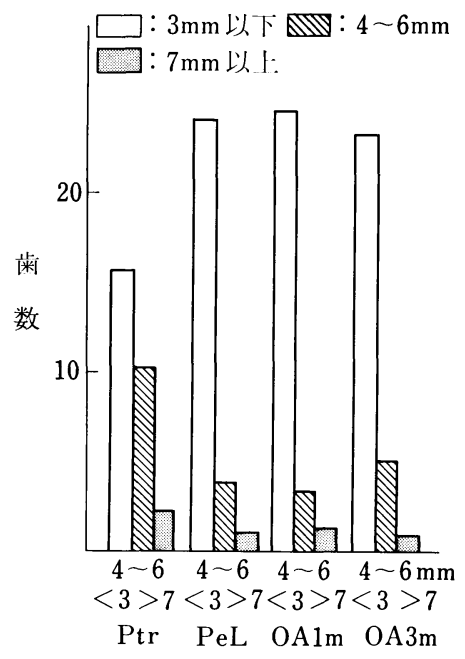

図 8 歯周ポケットの経時的変動

Ptr, PeL, OA $1 \mathrm{~m}, \mathrm{OA} 3 \mathrm{~m}$ 注 6 と 同じ

周ポケット除去後 1 カ月 $(\mathrm{PeL})$ になると, 有意な減少 を示し, 以後その状態が咬合調整後 1 力月 $(\mathrm{OA} 1 \mathrm{~m})$, 咬合調整後 3 力月 $(\mathrm{OA} 3 \mathrm{~m})$ まで維持し続けた $(\mathrm{p}<$ 0.01 )。

\section{2）咬合音波形の経時的変化}

初診時の波形には, impact 型と slide 型が混在した波 形が多い。中には，2 相性を示すものもみられた。歯周 ポケット除去 1 カ月後 (PeL) の波形は基本的に初診時 と変化は認められないが咬合調整を行うことにより,
表 3 動摇歯数の検定表（ $\mathrm{t}$-検定）

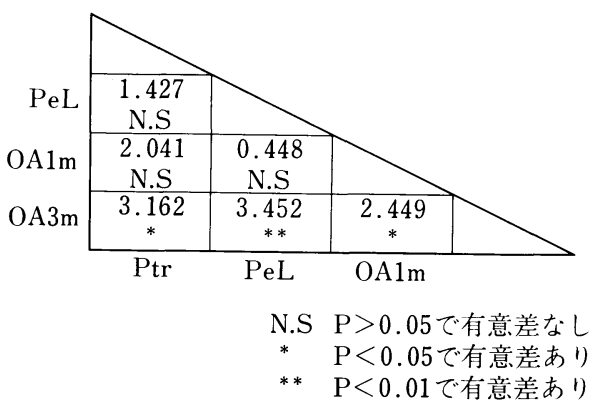

Ptr,PeL,OA1m,OA3mは図6と同じ

表 4 歯周ポケツトの検定表（t-検定）

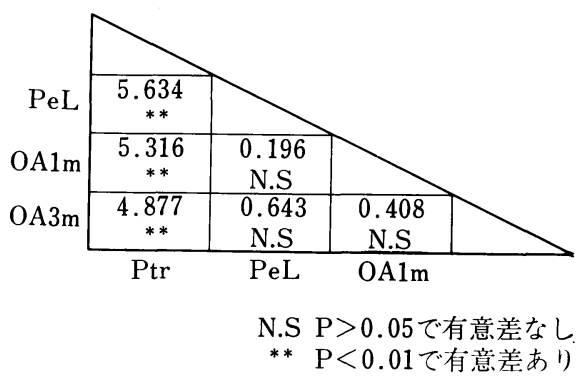

Ptr,PeL,OA1m,OA3mは図6と同じ

impact 型の波形が多くなった。その後，1 力月， 3 力月 経過しても, その傾向は持続され, かつ典型的な impact 型波形を示すものがより多くみられる傾向にあった。

\section{3） duration の経時的変動}

図 6 は正常咬合者同様，歯周炎䍜患者の各時期におけ る duration の平均值と標準誤差の変動を示したもので ある。なお，平均值はいずれも， 1 時期に測定した被検 者 1 人当り 10 回のサンプリング值（正常咬合者 11 名, 歯周炎罹患者 10 名）から求めた。

歯周炎罹患者の duration は初診時 $16.9 \pm 0.9 \mathrm{msec}$ (10. 9 20. $8 \mathrm{msec})$, 咬合調整前の歯周ポケット除去後 1 力月は, $15.4 \pm 0.9 \mathrm{msec}(9.3 \sim 19.7 \mathrm{msec})$, 咬合調整直 後 $12.4 \pm 0.9 \mathrm{msec}(7.8 \sim 17.1 \mathrm{msec})$, 咬合調整後 1 力 月 $11.1 \pm 1.1 \mathrm{msec}(8.0 \sim 17.2 \mathrm{msec})$, 咬合調整後 3 力 月 $10.9 \pm 1.5 \mathrm{msec}(5.6 \sim 19.0 \mathrm{msec})$ と経時的に減少 し，正常咬合者值に近づく傾向がみられた。表 5 は，こ れら変動值を $\mathrm{t}$-検定したもので, 初診時と歯周ポケッ 卜除去後 1 力月との間では有意差なく $(\mathrm{p}>0.05)$, 以後 咬合調整直後，咬合調整後 1 力月， 3 力月のいずれとも 
表 5 Duration の検定表（ $\mathrm{t}$-検定）

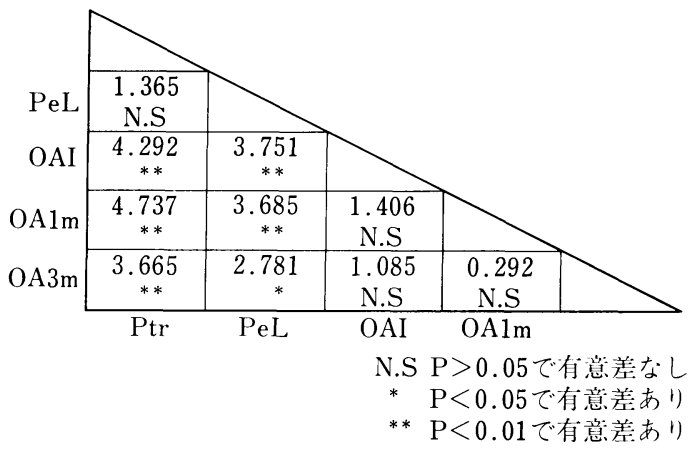

Ptr,PeL,OAI,OA1m,OA3mは図6と同じ

有意差が認められた $(\mathrm{p}<0.01)$ 。

\section{4）サンプリング回数の増加に伴う duration の変動}

図 9 は正常咬合者と歯周炎罹患者のサンプリング回数 とdurationの関係を示す。正常咬合者 11 名, 歯周炎罹 患者 10 名の各サンプリング時の duration 平均值の変動 をみると, 正常咬合者の咬合調整前後，ならびに歯周炎 罹患者の初診時を除いた他の時期のいずれにおいても, サンプリング回数の増加とともに duration は，ある変 動をもって短縮する傾向にあった。一方，歯周炎罹患者 の初診時では，各サンプリング時に值のバラッキが大き く，そのような傾向は認められなかった。

\section{5）症例報告}

症例 1 .

患者は 42 歳の女性。主訴は, ブラッシング 時, 下頢 前歯部の出血と鈍痛である。初診時問診により，軽度の 糖尿病に罹患し，食事療法を受けていることが判明し た。口腔内所見は，図 10 に示すとおり，多量の歯石が 下顎前歯の周囲に沈着しており，その部の歯肉の辺縁に は強い炎症がみられた。この部の歯周ポケットは 1 〜 3 $\mathrm{mm}$ と比較的浅いが，歯槽骨は約 $40 \%$ の水平性吸収が みられる (図 11)。臼歯部では 4 6 $\mathrm{mm}$ の樑い歯周ポケ ットが上顎で 12 部位，下顎では 6 部位存在していた。 また，前歯及び曰歯あわせて 17 歯に軽度の動摇がみら れた。本症例は下滪前歯部に咬合性外傷を伴う中等度の 歯周炎と診断した。歯周初期治療として, プラークコン トロール，歯石除去とルートプレーニング，咬合調整な ぞを行った。歯周初期治療の結果，主訴に関する患者の 悩みは解消され，同時に歯周組織も明らかに改善され た。すなわち，治療前に存在していた歯周ポケット 4 〜 $6 \mathrm{~mm}$ の 18 部位が治療後, 2 部位に減少した（図 12）。 これらの変化に対して，咬合音波形は，図 13 に示すご

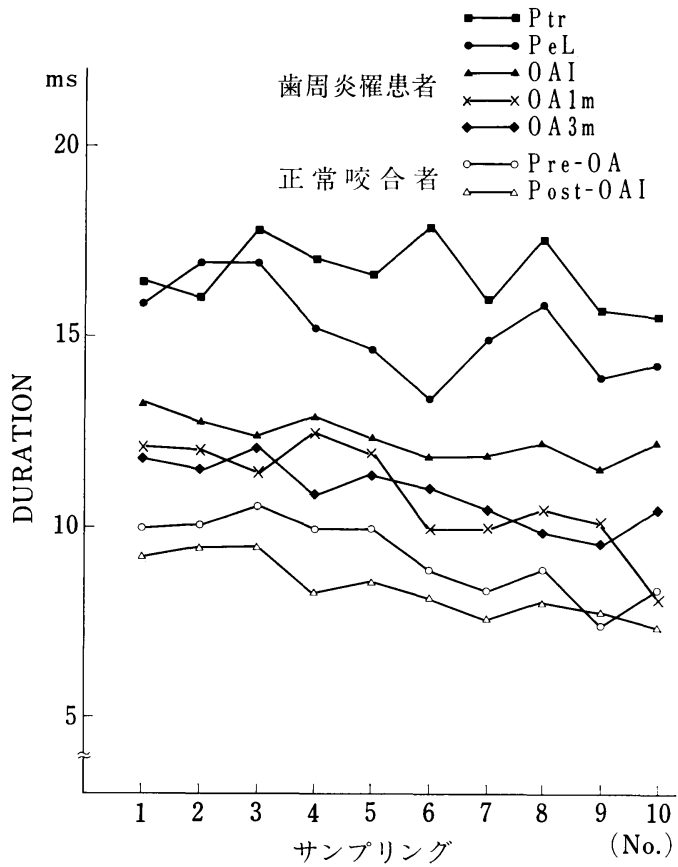

図 9 サンプリング回数と duration との関係 Ptr, PeL, OAI, OA1m, OA3m, Pre-OA, Post-OAI は図 6 と同じ

とく, 歯周ポケット除去前後において, 初診時 (Ptr) と 歯周ポケット除去後 1 力月（PeL） との間の波形に大き な変化，すなわち, impact 型波形と slide 型波形とが入 りまじった波形から simple な impact 型波形に変化し た。その時期の duration は $17.9 \mathrm{msec}$ から $9.3 \mathrm{msec}$ と減少した。咬合調整後の波形はより impact 型の波形 の傾向をとり, duration も咬合調整直後 $8.0 \mathrm{msec}$, 咬合 調整後 1 力月 $8.0 \mathrm{msec}$, 咬合調整後 3 力月 $7.8 \mathrm{msec}$ と 短縮する傾向が認められた。

症例 2

咬合性外傷を伴う軽度な歯周炎である。咬合性外傷歯 は臼歯部に存在していた。咬合音波形の経時的変動を図 14 に示す。初診時と歯周ポケット除去後 1 力月の間で は，波形パターンにあまり変化なく，咬合調整直後にな ると, impact 型波形に大きく変化し, 調整後 1 力月, 3 カ月もその状態が持続した。duration は，初診持 13.6 $\mathrm{msec}$ から歯周ポケット除去後 1 カ月で $14.1 \mathrm{msec}$ とや や延長するも，咬合調整直後になると $7.8 \mathrm{msec}$ に短縮 し, 以後咬合調整後 1 力月 $8.0 \mathrm{msec}, 3$ 力月 $9.1 \mathrm{msec}$ とその状態が維持された。 

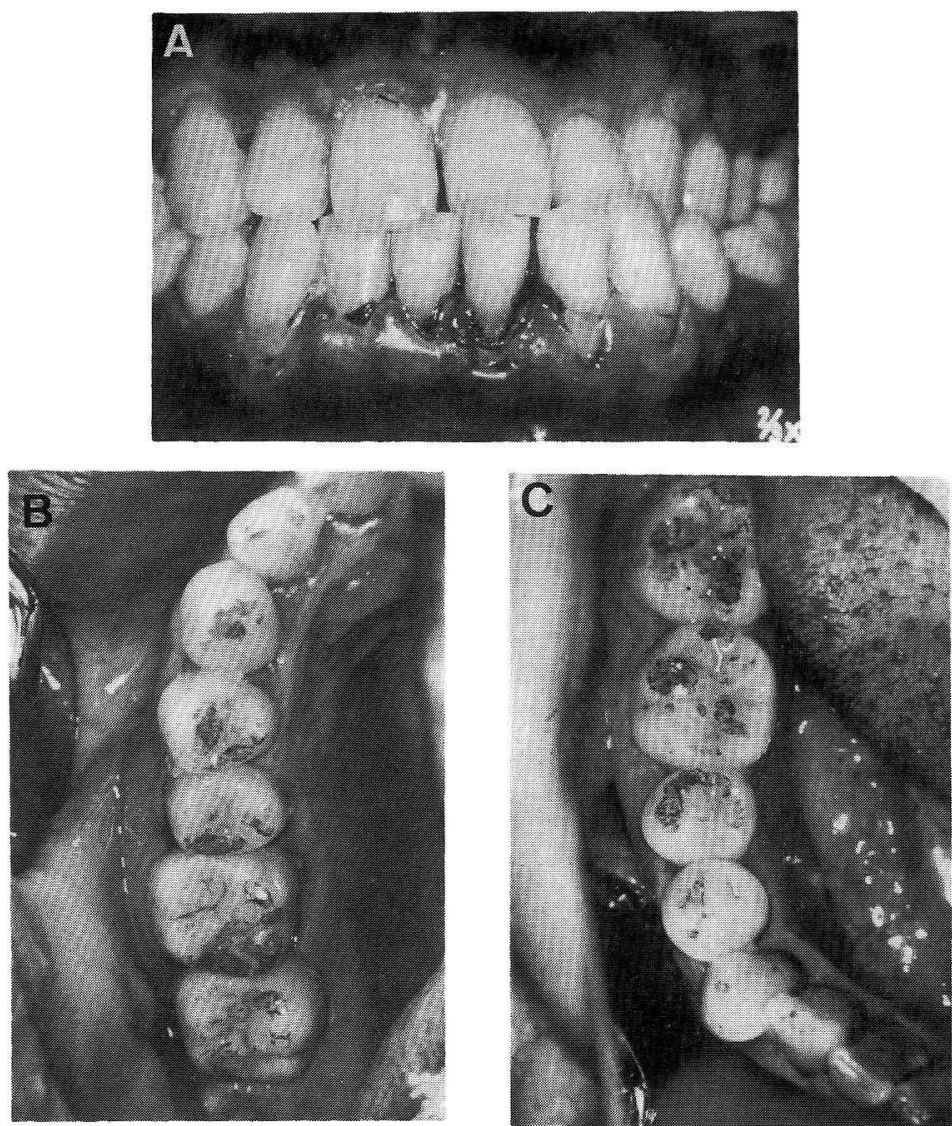

図 10 下顎前歯部に咬合性外傷を伴う歯周炎罹患者（症例 1 )

A : 初診時, 下顎前㐘部に歯石沈着と柬肉に強い㷋症がみられる

B，C：ともに咬合印記は咬合の位置異常と強い面接触を示す

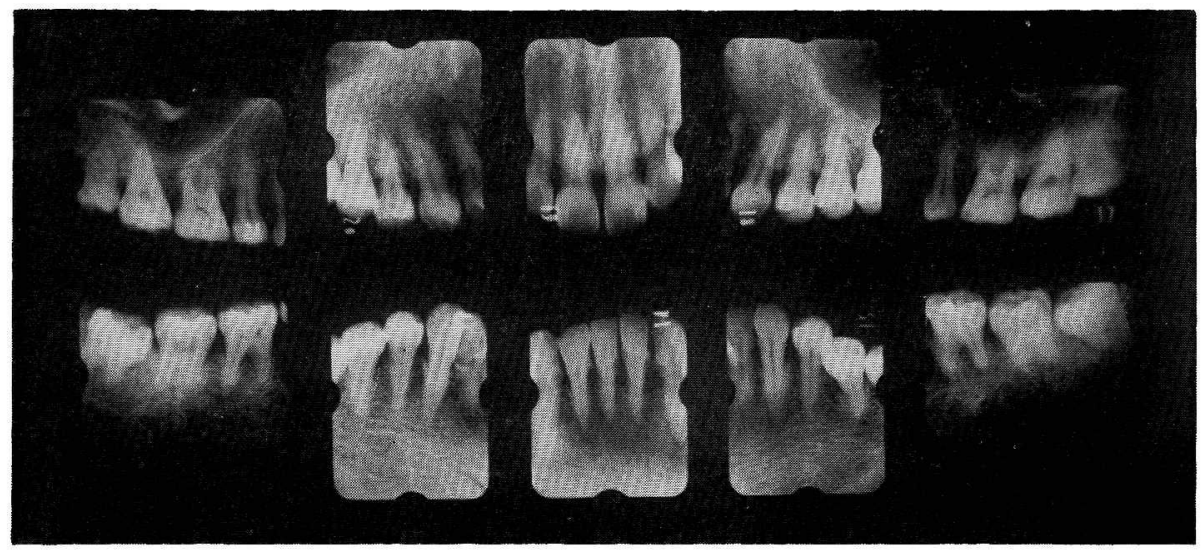

図 11 症例 1 の線像

初診時, 下顎前歯部と上顎第 1 大曰歯で惄の吸収が強く, 他の部位での吸収は比較的軽、 

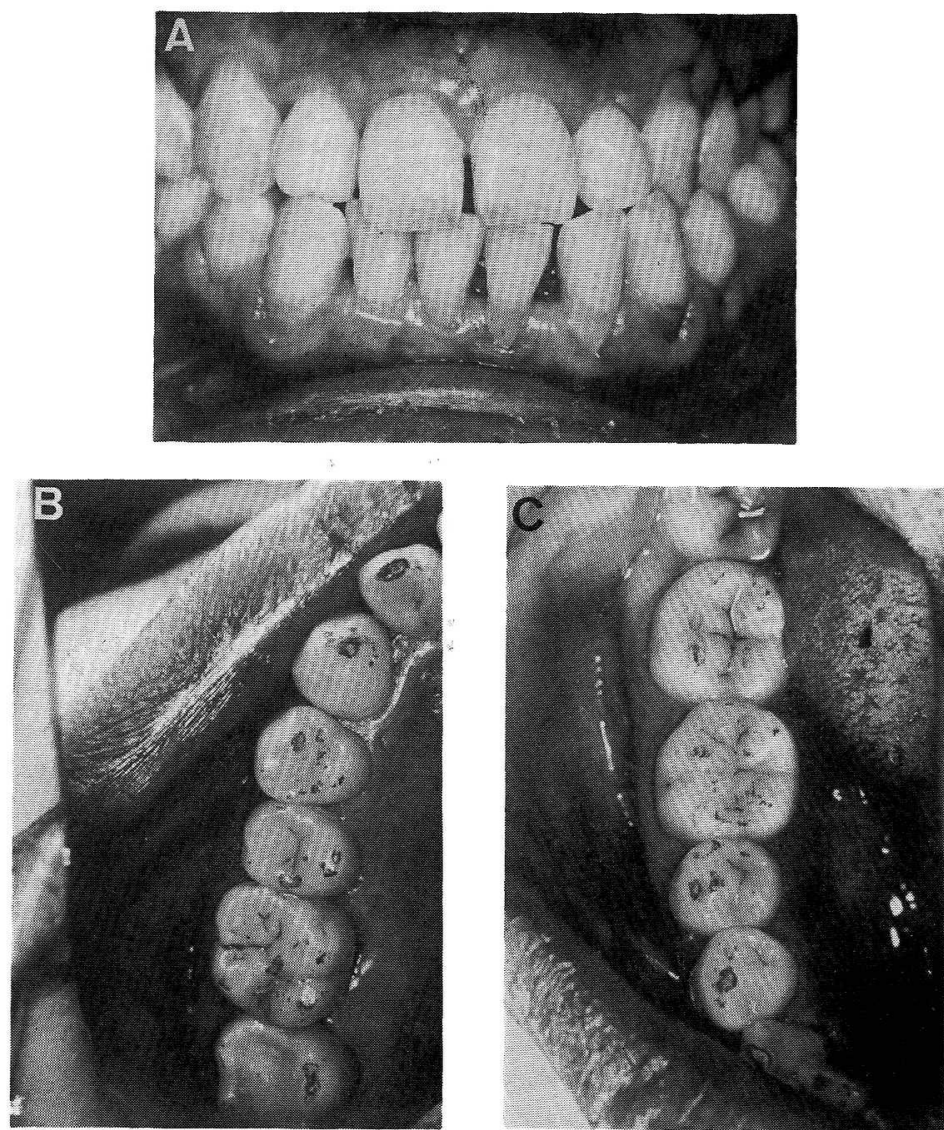

図 12 初期治療後 5 力月経過 (症例 1)

A：歯肉の炎症は消退し, 改善された

B，C：ともに咬合は至適な位置と接触に修正された

症例 3

本症例は咬合性外傷を伴う中等度の歯周炎と診断され た。図 15 は咬合音波形の経時的変動を示す。波形パタ ーンは, 症例 2 と同椂, 初診時と歯周ポケット除去後 1 カ月の閒では変化がなく, 咬合調整後に slide 型パター ンから impact 型パターンに変化した。その duration は, 初診時 $19.5 \mathrm{msec}$ から歯周ポケット除去後 1 力月 $17.9 \mathrm{msec}$ となり, 咬合調整直後 $13.5 \mathrm{msec}$, 咬合調整 後 1 力月 $8.4 \mathrm{msec}$, 咬合調整後 3 力月は $5.6 \mathrm{msec}$ と減 少した。

\section{考察}

本研究の対象となった正常咬合者及び歯周 炎罹患者 は，ら蝕がなく歯冠修復及び補緅的に何ら処置されてい
ない天然歯 28 歯を有し，まったく久損歯のみられない 被検者である。上下顎歯をタッピングさせたときに，歯 冠修復又は補緅物が介在していた場合, 発生する咬合音 に対する影響は大であると考えられる。補緅物の中で義 歯に由来する咬合音は，天然歯で聴くことのできない 「follow box 音」が存在する, double click 音などが関 係するといわれている(19)。また, 歯が变失し隣在歯が傾 斜, 移動したりすると, 異常な早期接触や滑走の原因に なる ${ }^{20)}$ 。また, 久損歯が片側に多く存在する場合は偏位 咬合となり，異常な咬合音を発生させる原因となる。以 上のような理由から咬合音をサンプリングするさいの再 現性といら点で, 今回被検者の選択を厳選した。これら の測定分析器を取り扱う場合, 術者は機器の操作性, デ 一夕の再現性, 信頼度などについて, 十分な知識と準備 を整えることが必要である。そこで，著者は次の操作順 

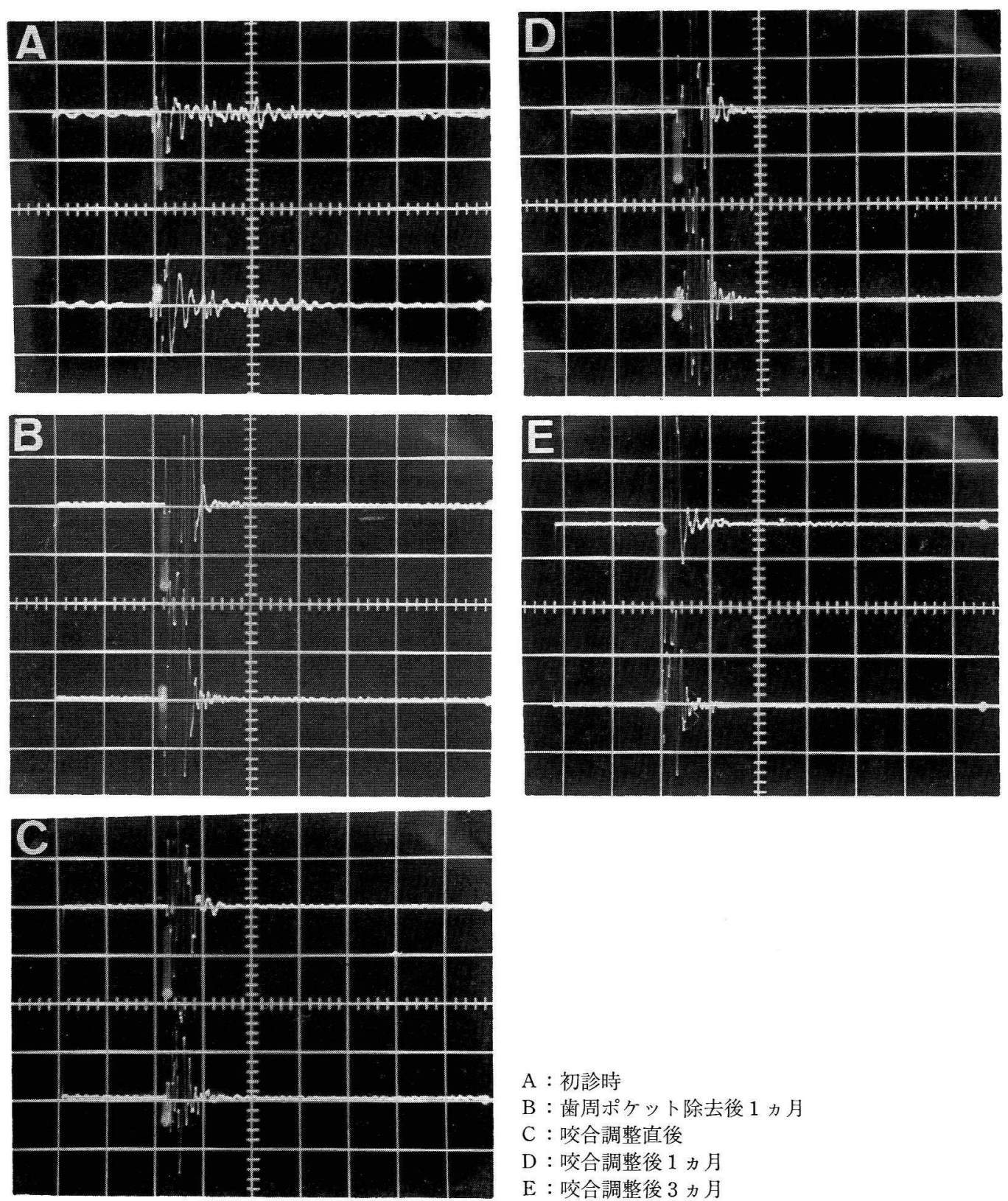
A : 初診時
$\mathrm{B}$ : 歯周ポケット除去後 1 力月
C：咬合調整直後
D：咬合調整後 1 力月
$\mathrm{E} ：$ 咬合調整後 3 力月

図 13 症例 1 の咬合音波形

序に従ってサンプリングを行った。まず，咬頭嵌合位で 約 20 回のタッピングの練習をさせたのち，10 回のタッ ピングの振幅が一定の高さとなる波形を記録した. この 場合, 振幅の高さに変化が生じると, 波形の型や, duration に影響を与えて, サンプリングの再現性を失 う恐れが生じたからである。波形の判定に際して,
雨宮 ${ }^{21)}$ は, タッピングの強弱によって波形に変化が 生じるため, 数回以上, 咬合音の連続的観察が必要 であると述べている。Watt ${ }^{22)}$ は, 同じ咬合状態で 偏位しない咬合を繰り返す限り, 咬合音波形は変わ らないことを観察している。従って本研究に打ける 咬合音のサンプリング操作方法は, 被検者に対し, 

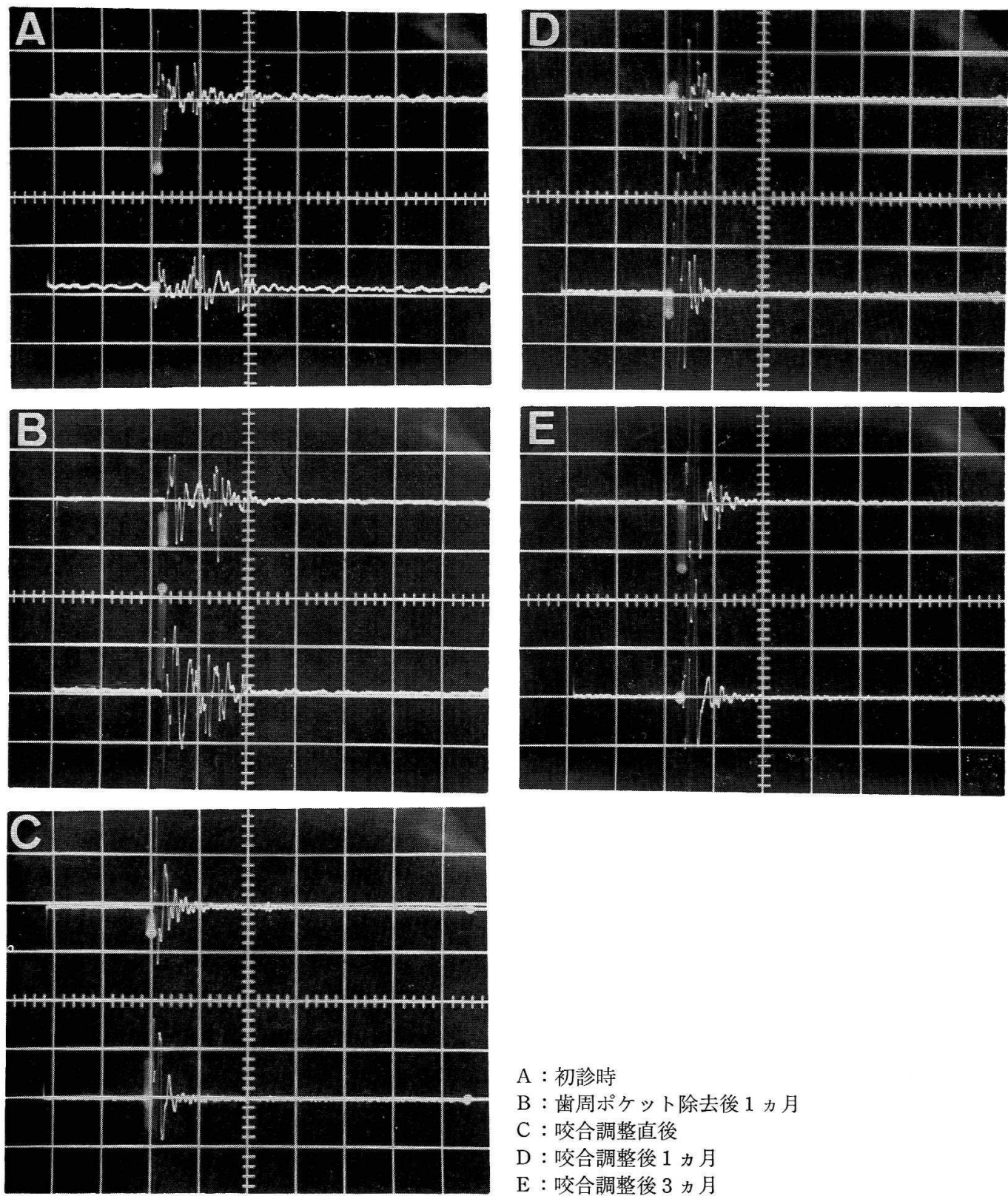
A：初診時
B：歯周ポケット除去後 1 力月
C : 咬合調整直後
$\mathrm{D}$ ：咬合調整後 1 力月
$\mathrm{E} ：$ 咬合調整後 3 力月

図 14 症例 2 の咬合音波形

咬頭嵌合位でしかも同じ強さのタッピング練習を行わせ ることにより，再現性のある咬合音波形を得るのに良好 であったと考えられる。

咬合音の集録に際しての重要なポイントは，マイク口 フォンの装着部位の決め方である。今回の研究で使用し たマイクロフォンの装着部位は，眼窩下煩骨部と定め,
マイクロフォンをヘッドギヤで固定した。その部は解剖 学上, マイクロフォン辺縁と顔面皮膚との間の封鎖性に 適した部位と考えられる。

咬合音の分析法は，次のように大別される。

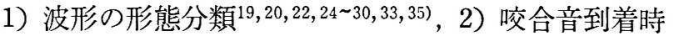
間の測定 ${ }^{36)}$, 3) 強度差の測定 ${ }^{21,32)}$,4) 咬合音持続時間の 

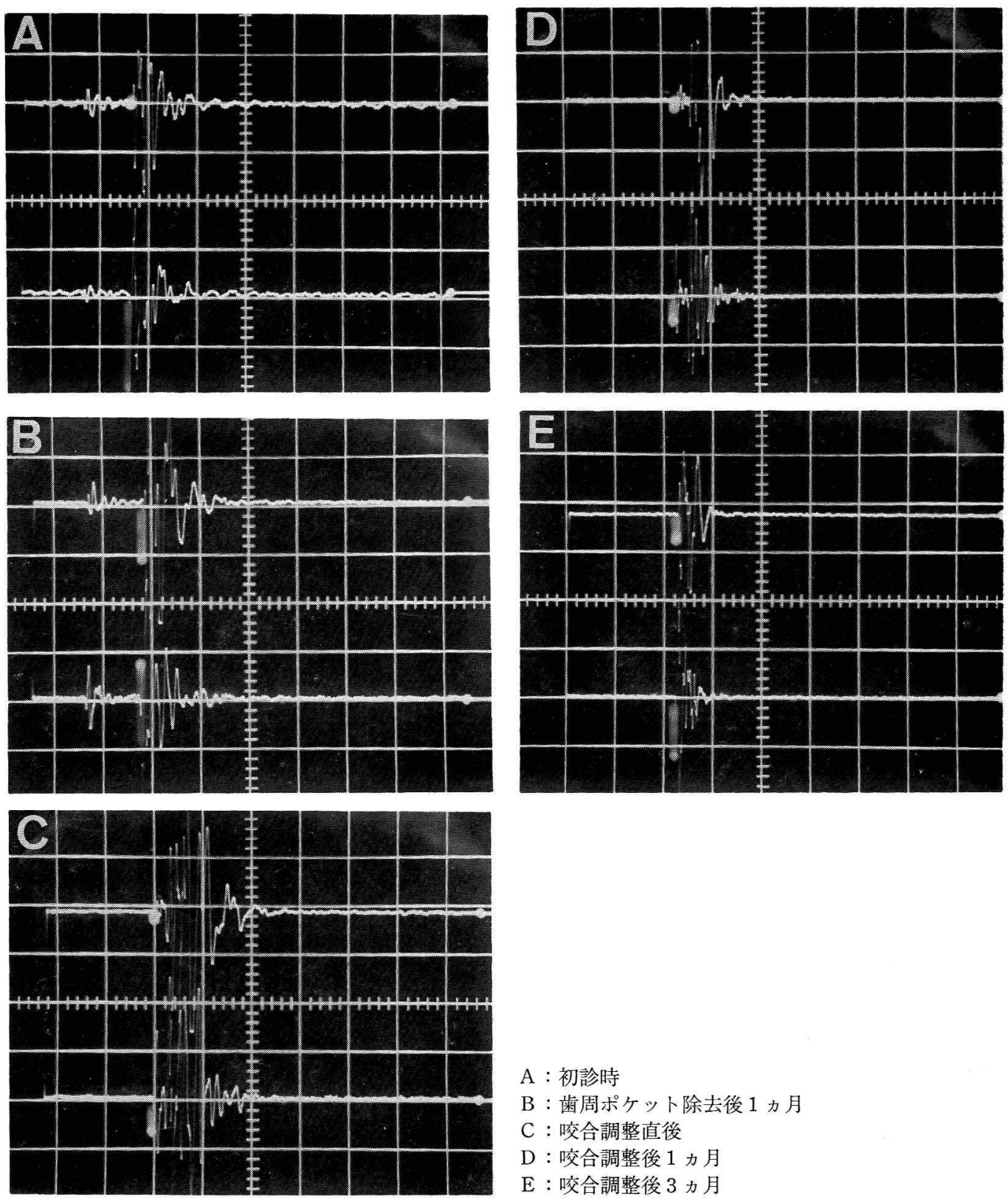
A : 初診時
$\mathrm{B}$ ：歯周ポケット除去後 1 力月
C : 咬合調整直後
$\mathrm{D} ：$ 咬合調整後 1 力月
$\mathrm{E}:$ 咬合調整後 3 力月

図 15 症例 3 の咬合音波形

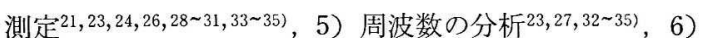

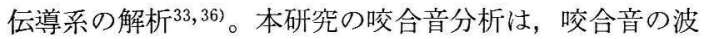
形と duration について行った。Watt ${ }^{25)}$ は咬合音波形 を impact 型と slide 型に分類し，これらは咬合の安定， 不安定に結びつくと述べている。しかも波形は duration と密接な関係を有し, impact 型は short duration
を示し，一方 slide 型は duration が長くなることを示 した。

本研究においても，X-Y ペンレコーダで記録した波形 から duration と波形パターンの変化が認められた。つ まり, impact 型と slide 型が複雑に組み合わされ, durationの長い波形が, 咬合調整後に impact 型で duration 

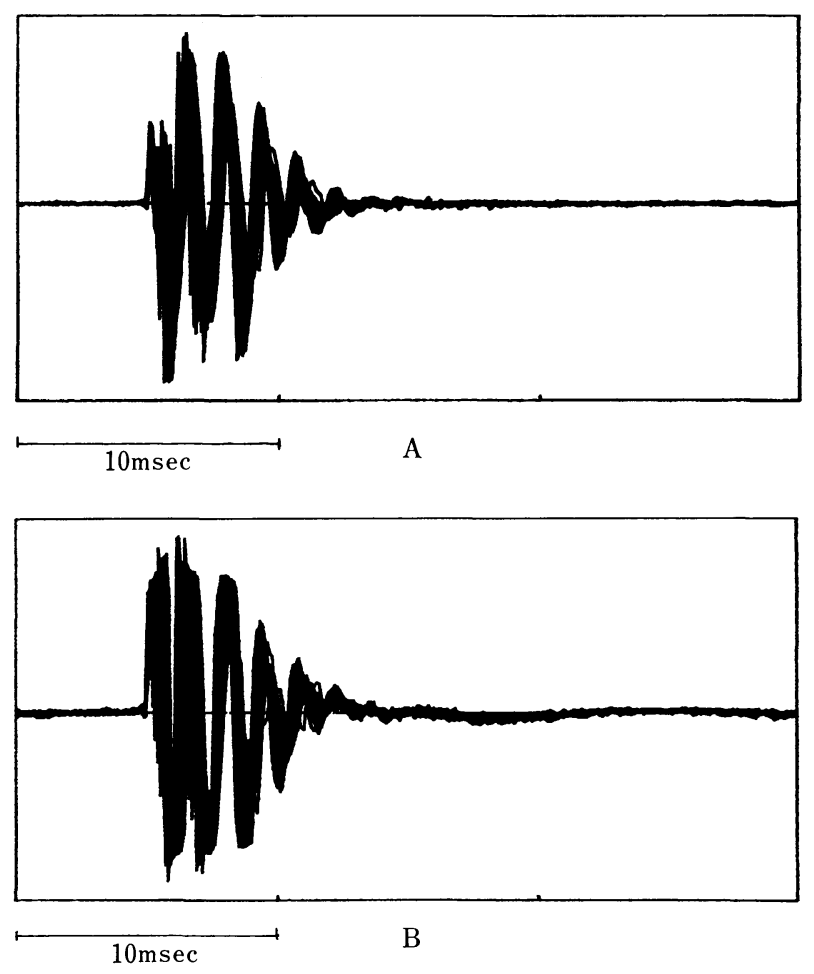

図 1630 回タッピングさせ, 記録した波形の重ね合わせ
A : Filter on
B : Filter off

の短い波形に移行した。

咬合音波形の duration は, 波形の最初の立ち上がり から減衰にいたる波形の末端部（終末部）までの長さを 時間で読みとる。この際，波形の末端部が咬合音波形の 末端部であることを的確に決定しなければならない。し かし，波形の末端部においては，低周波成分の本来の咬 合音のほかに, 外部雑音, マイクロフォンとその設置部 位の軟組織間での共振など, 種々の artifacts が複雑に 影響を及ぼし合い，末端部決定に際し，困難な場合が多 い。そこで著者らは, $350 \mathrm{~Hz}$ 以下の低周波領域を H.P. F. (High Pass Filter, fc $=0.35 \mathrm{kHz}$, 減衰特性 $40 \mathrm{~dB} / \mathrm{de}$ cade) でカットすることにした。ここで，フィルターを 導入した(Filter on) 場合と導入しない (Filter off) 場 合との波形間で相異のないことを確認することにした。 まず，正常咬合者 1 名に Filter on の場合と Filter off の場合, 各々 30 回ずつタッピングを行わせ，それらの 波形を重㸚合わせてみると, 図 16 に示すと打り, 両者と も最初に impact な立ちあがりをみせた後, 徐々に減衰 する波形を示し, ほぼ一致していた。その際, 計測した duration は, $10 \mathrm{msec}$ 付近で差異がないことを確認し た。次に, 図 17 は, Filter on と Filter off の際のタッ ピング 30 回のパワースペクトルを重ね合わせたもので, 両者とも低周波領域で重なりをみせ, $0.7 \mathrm{kHz}$ 付近にお いて, ピークを示し, 高周波領域では重なりが悪いこと を確認した。以上の結果から, フィルターの導入は, 咬 合音波形の末端部の決定を容易にさせ，しかも，咬合音 波形, duration, および周波数成分において, 導入しな い場合との間に差が生じないことから, 適切な手段であ ったと考える。

Brenman ら ${ }^{29,30)}$ は, 早期接触歯のタッピング音の 持 続時間は正常咬合歯に比較して明らかな違いがみられた と述べている。

また，Watt は，咬合音および顎関節音をテープレコ 一ダに録音し, 再生速度を変換してオシログラフに描 記させる方法により，一連の詳細な検討を行ってい $ろ^{19,20,22,24 \sim 27,37 \sim 40)}$ 。Watt は咬合音, 哣関節音による検 查術式を Gnathosonics と称し, 咬合の安定, 不安定さ が判別できるとして, 咬合解析の有力な手段として将来 


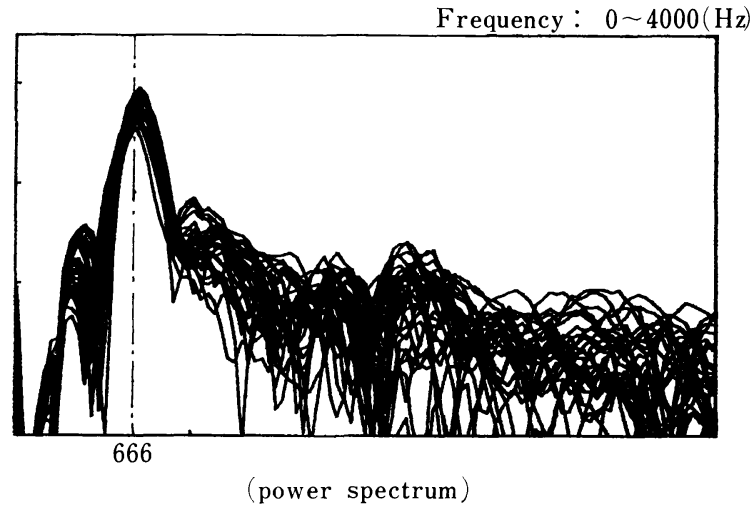

A

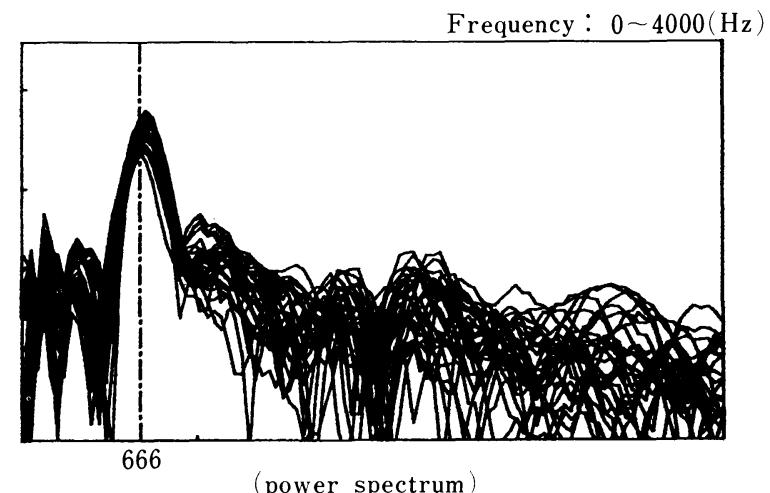

B

図 1730 回タッピングさせたときのパワースペクトル 分布 (推定方法 : FFT)

A : Filter on

性があると説いている20,22,24, 25,38,40)。一方，本邦では， 織田 ${ }^{32)}$, 石岡ら ${ }^{23)}$ が咬合音の周波数のパワースペクトル を求め, 咬合音の原波形と比較分析を行っている。さら に雨宮 ${ }^{21)}$ は, 正常咬合者の強いタッピング波形は立ち上 がりから大きい振幅の spike を示して漸減する三角形型 と弱いタッピング波形の中間にピークが位置する菱形型 とに分類するなど, Watt の方法に準じて, 各種の咬合条 件下における咬合音の波形の分類及び持続時間につい て，検討を加えている。同様に，高橋 ${ }^{41)}$ は正常咬合者の タッピング原波形は, 衝突型であり, そのパワースペク トルを求めたところ, 第一低帯域, 第二低帯域, 中間帯 域, 高帯域に分けられ, 各帯域の主成分の平均はそれぞ れ $250,3,800,6,650 \mathrm{~Hz}$ であったと述べている。さらに 衝突以前にわずかな滑走を思わせる波形を含んでいる症
例もみられたと述べている。

本研究における正常咬合者 11 名は, 全歯にわたり 2 $\mathrm{mm}$ 以下の歯肉溝を有し, $X$ 線学的にも歯根膜, 歯槽骨 に何ら異常を示さず, 歯列の異常, 歯の動摇のない比較 的安定した咬合を営んでいる症例であった。咬合印記 の状態も，歯周炎罹患者にくらべ接触面積は小さく，接 触の位置異常をきたしている場合も少なかった。これら 正常咬合者 11 名の咬合音波形は, 咬合調整の有無に関 係なく, impact 型の波形が主体を占めていたが, 1 症 例に 2 相性波形が認められた。これは, 最初, 早期接触 が起こり, ついで滑走運動, 最後に咬頭嵌合位で咬合接 触するさいに発生した波形の組み合わせであると考えら れる。正常咬合者の咬合調整後は, 全体的に, より impact 型波形の出現が多くなり, duration も明らかに減 
少し, $10 \mathrm{msec}$ 以下で安定する傾向を示した。このこと は，咬頭嵌合位におけるタッピングが咬合調整によっ て，早期接触や咬合干涉などによる滑走運動が少なくな り, 全歯が至適な位直 ${ }^{5 ~ 8)}$ で均一に接触する安定した 咬 合関係に改善されたことを示すものである。正常咬合者 の duration は, $9 \mathrm{msec}^{31)}, 9 \sim 26 \mathrm{msec}^{30)}, 36.2 \mathrm{msec}^{21)}$, $40 \mathrm{msec}^{26)}$ と報告はまちまちであるが，このことは，本 研究の結果を含めて, サンプリングの方法, 波形の末端 決定の認識法, 波形の記録装置の機種と使用方法などが 異なること, また, 本研究のように正常咬合者に咬合調 整を行って至適な位置でまたは均一に接触するように咬 合接触させるか否かによっても測定值は変動するものと 考えられる。

咬合性外傷を伴う歯周炎罹患者 10 名に対する歯周組 織の診査用パラメータとして, 著者は, 歯の動摇度, 歯 周ポケットの樑さを採用した。咬合性外傷の臨床的徴候 の中で, 歯の動摇の増加が最も頻回にあらわれる徴候で ある。しかも，歯の動摇に影響する因子として歯根膜の 性状があり, 歯肉の付着または歯根膜病変の改善は歯の 動摇の減少をきたす42 48)。歯周ポケットの深さの減少 は, 歯肉の炎症の消失, または歯の再付着のいずれか, またはともに起こったことを示す。例えばプラークコン トロール，歯石除去，ルートプレーニングにより $4 \mathrm{~mm}$ 以上の歯周ポケットは多数消失し, その状態が咬合調整 後 3 カ月まで維持できたこと, 歯の動摇は初診時に対し て歯周ポケット除去後 1 力月, 咬合調整後 1 力月の時期 はともに変化を示さず，咬合調整後 3 力月で有意に減少 した。咬合音波形の経時的変化をみると，歯周ポケット 除去後に波形パターン並びに duration は基本的に初診 時と変りなく，咬合調整後に波形は impact 型に移行し， duration は有意に減少した。このことは, 加藤 ${ }^{42,46)}$ がま た，咬合性外傷罹患歯に咬合調整を行ったところ，4週 間後に歯の共振振動数は正常值に近づいたとのべている ようにこの時期の歯周組織は, 歯周ポケット除去と咬合 調整の両方の効果により歯の動摇が減少し，それに伴な い咬合が安定したものと考えられる。サンプリング回数 の増加に伴なう duration の変動についてはその回数の 増加とともに duration は減少傾向が認められた。サン プリングを 1 回行うに際して, 約 10 回のタッピングの 練習をさせており, 10 回目のサンプリング時の duration 值は, 100 回タッピングさせたときの計測值となる。こ のことはタッピングに対する被検者の慣れが生じ, duration が漸次短縮したものと考えられる。また 1 度に 100 回のタッピングは, この種の計測の信恣性からみて限度
と考える。

筋電図測定のパラメータとして, Silent Period を採用 した ${ }^{49 \sim 52)}$ 。Silent Period の特徵は, 顎口腔系機能を調 節する神経一筋機構に関連した現象であることと, 筋電 図の波形中, 再現性の高いことがあげられる。本研究の 結果から, Silent Periodの波形は歯周治療後に安定化 し，再現性の高いことが証明された。

\section{総括ならびに結論}

本研究は, 咬合音診査のうち咬合音診断機器 (デンタ ルサウンドチェッカーTME 202 C 型, ヨシダ社製）を 使用して咬合音波形パターンの記録, 分析と咬合音持続 時間（duration）の測定を行った。被検者はう蝕がなく 補緅的に何ら処置されていない天然歯 28 歯がすべて揃 った正常咬合者 11 名と咬合性外傷を伴った歯周炎罹患 者 10 名を選んだ。

咬合診査ならびに咬合音の測定は正常咬合者の場合, 咬合調整 (歯冠の形態修復) 前後に，歯周炎罹患者では 初診時, プラークコントロール, 歯石除去とルートプレ 一ニングの処置による歯周ポケット除去後 1 力月, 咬合 調整直後, 咬合調整後 1 力月, 3 力月の各時期に行っ た。なお，全被検者とも実験中，プラークスコアは $20 \%$ 以下に維持させた。

結果は次のとおりである。

1）咬頭嵌合位でのタッピング時, 患者をリラックス させた状態で咬合音を測定すると咬合音波形パターンな らびに duration は比較的バラツキが少く再現性がある。

2）健康な歯周組織，正常な歯列を有する正常咬合者 の波形は，一般に impact 型で duration は $10 \mathrm{msec}$ 以 下と安定していた。

3）咬合性外傷を伴う歯周炎罹患者は，一般に歯周治 療前，咬合は不安定で波形は slide 型で duration も平 均 $16.9 \mathrm{msec}$ と長い。しかしながら，咬合調整を含む歯 周初期治療後に, 咬合音波形は impact 型で安定化し, duration は $10 \mathrm{msec}$ に近づいた。

4）咬合性外傷を伴う歯周炎罹患者に，咬合調整を含 む歯周初期治療を施したところ，歯周ポケットは，歯周 ポケット除去後に, あきらかに消退し, 咬合調整後 3 カ 月までその状態が維持できた。歯の動摇は歯周ポケッ 卜除去後, 咬合調整直後, 咬合調整後 1 力月まで有意な 軽減がみられず，咬合調整後 3 カ月になると，明らかに 減少した。

5）咬合調整を含む歯周初期治療の効果を知るのに, 
咬合音波形パターンの分析と duration を測定すること は有効な手段といえる。

謝辞: 稿を終るにあたり, 終始御懇篤なる御指導と御校閲を 賜りました原 耕二教授に心から感謝申し上げます。また本研 究の遂行に際し郎切丁寧な御教示ならびに御助言を賜りました 本学補緅学第 1 教室石岡 靖教授, 山鹿卓郎講師, 林 豊彦助 手, ならびに本学予防菌科学教室堀井欣一教授, 滝口 徹助手, さらに新潟大学工学部情報工学科木竜 徽講師に謹んで感謝の 意を表します。また本研究に御援助，御協力いただきました本 学保存学第 2 教室貴船亮英助手, 大学院生山下 董氏各位に深 謝いたします。なお，咬合音診断機器の操作全般について，多大 なる御助力いただきました株式会社ヨシダおよび藤栄電気株式 会社に謝意を表します。

本研究の一部は, 昭和 57 年度日本歯科医学会学術研究费短期 研究の補助で行われたことを付記する。

\section{文献}

1) Stahl, S.S. : Accomodation of the periodontium to occlusal trauma and inflammatory periodontal disease. Dent. Clin. North Am., 19: 531-542, 1975.

2) Glickman, I. and Smulow, J.B. : Effect of excessive occlusal forces upon the pathway gingival inflammation in humans. J. Periodontol., $36:$ 141-147, 1965.

3) Glickman, I. and Smulow, J.B. : The combined effects of inflammation and trauma from occlusion in periodontitis. Int. Dent. J., $19: 393-$ 407, 1969.

4) Comar, M.D., Kollar, J.A. and Gargiulo, A.W.: Local irritation and occlusal trauma as co-factors in the periodontal disease process. J. Periodontol., $40: 193-200,1969$.

5）原 耕二, 中島 真, 山岸 茂: 咬合性外傷と歯 冠の形態修復. 日本歯科評論, 427 号 : 57-65, 1978.

6）池田克巳, 上羽隆夫, 原 耕二共訳 : 歯周疾患の 咬合治療．医歯薬出版，東京，1976，248-287.

7）中島 真, 山岸 茂, 原 耕二: 咬合性外傷々歯 冠の形態修復. 日歯周誌, $20: 98-105,1978$.

8）池田克巳, 原 耕二 : 咬合調整, 中静 正他, 歯 周治療の手引き, 書林, 東京, 1978, 191-202.

9）池田克巳 : 咬合の調整とブラキシズムの処置, 中
静 正，石川 純編，歯周治療学．医歯薬出版， 東京, 1981，265-272.

10) Goldman, H.M. and Cohen, D.W. : Periodontal therapy. 6 th edit., C.V. Mosby Co., St. Louis, 1980, 1106-1107.

11）林 豊彦, 石岡 靖: 咬合音の採取方法ならびに 機器：歯科ジャーナル, $17: 557-566,1983$.

12）本間修平, 福永隆四, 吳 輝 逢, 佐藤 純平, 原 耕二 : 咬合治療の効果と咬合音診断. 日歯周誌, $24: 456-466,1981$.

13）佐藤純平, 中島 真, 柳村光宽, 原 耕二 : 歯冠 の形態修復による咬合治療の予後 観 察. 日歯 周 誌, $22: 627-642,1980$.

14）山鹿卓郎：咀嚼笳筋電図分析による顎口腔系機能 異常診断とその臨床応用に関する 研 究. 日 補 緅 誌, $27: 50-73,1983$.

15）渡辺富栄，岡田美和子，吉江弘正，山岸 茂，原 耕二 : 臨床上効果的でかつ容易に実施できるプラ ークコントロールプログラムの確立. 日歯周誌, $25: 385-392,1983$.

16）原沢正昭，神谷洋行，浦田淑子，丸山栄子，神田 敬子, 原 耕二 : プラーク付着の歯肉組織への影 響に関する臨床的研究. 日歯周誌, $23: 327-338$, 1981.

17) O'Leary, T.J., Drake, R.B. and Naylor, J.E. : The plaque control record. J. Periodontol., 43 : 38, 1972.

18) Yukna, R.A. and Lawrence, J.J. : Gingival surgery for soft tissue new attachment. Dent. Clin. North Am., 24 : 705-718, 1980.

19) Watt, D.W. : A preliminary report on the auscultation of the masticatory mechanism. Dent. Practit., 14 : 27-30, 1963.

20) Watt, D.W. : Clinical applications of gnathosonics. J. Prosthet. Dent., $16: 83-95,1966$.

21）雨宮幸三：咬合音に関する研究. 歯科医学， 40 : 239-261, 1977.

22) Watt, D.M. : Gnathosonics-A study of sounds produced by the masticatory mechanism. J. Prosthet. Dent., 16 : 73-81, 1966.

23）永木修二, 野村修一, 風間栄輔, 石岡 靖: 䫟 口腔における音響・振動に関する研究. 第 1 報 咬合音について。 日補緅誌，19:43-58，1975.

24) Watt, D.M. : A gnathosonic study of tooth 
impact. Dent. Practit., 17 : 317-323, 1967.

25) Watt, D.M. and Hedegard, B. : The stereostethoscope-An instrument for clinical gnathosonics. J. Prosthet. Dent. 18 : 458-463, 1967.

26) Watt, D.M. : Recording the sounds of tooth contact : A diagnostic technique for evaluation of occlusal disturbances. Int. Dent. J., 19 : 221238, 1969.

27) Watt, D.M. and Wakabayashi, Y. : Study of a classification of occlusion. J. Oral Rehabil., 5 : 101-110, 1978.

28）小鹿典雄 : 顎関節症における咬合音ならびに咀嚼 筋笳電図に関する研究. 歯科学報, $78: 535-586$, 1978.

29) Brenman, H.S. and Hattler, A.B. : Myograms and occlusograms. Dent. Progr., $3: 253-261$, 1963.

30) Brenman, H.S. and Amsterdam, M. : Postural effects on occlusion. Dent. Progr., $4: 43-47$, 1963.

31）小宮山彌太郎：天然歯列における咬合・接触状態, 歯牙の動きおよび咬音との関係について，歯科学 報, $75:$ 1699-1745, 1975.

32) 織田篤憲 : 咬合音の分 析. 歯 科医 学, $40: 239$ $261,1977$.

33）高宮紳一郎：咬合音の骨伝導に関する研究. 歯科 学報, $79: 1317-1359,1979$.

34）若林康郎，竹花庄治 : 咬合音分析に関する考察. 歯科ジャーナル, $8: 213-220,1978$.

35）小林義典：咬合音による咬合音診断に際しての臨 床的条件付け. 歯科ジャーナル， $17: 593-604$, 1983.

36） 中村正幸：歯に加わった衝撃の伝導特性. 歯科ジ ヤーナル, $17:$ 543-549, 1983.

37) Watt, D.M. : Report on a method of direct occlusal analysis. Dent. Practit., $15: 416-420$, 1965.

38) Watt, D.M. : Gnathosonics in occlusal evaluation. J. Prosthet. Dent., 19 : 133-143, 1968.

39) Watt, D.M. Sharkey, S.W., Saberi, M. and Likeman, P.R. : A study of the average duration of occlusal sounds in different age groups. Brit. Dent. J., 138 : 385-388, 1975.

40) Wakabayashi, Y. and Watt, D.M. : Gnathosonic monitoring of patients with gnathic dysfunctions. J. Oral Rehabil., 5 : 29-34, 1978.

41）高橋雅一：咬合音分析の矯正臨床への応用. 日矯 歯誌， $40: 228-250,1981$.

42) 加藤 哭 : 正常および病的な歯周組織の共振動数 の測定一歯周組織の生物学的診断の新しい方 法一。病誌, 35 : 58-81, 1968.

43) Kegel, W., Selipsky, H. and Phillips, C. : The effect of splinting on tooth mobility. I. During initial therapy. J. Clin. Periodontol., $6: 45-58$, 1979 .

44) O'Leary, T.J. : Indices for measurement of tooth mobility in clinical studies. J. Periodont. Res. Suppl. 9, 14 : Q4-105, 1974.

45) Kerry, G.J., Morrison, E.C., Ramfjord, S.P., Hill, R.W., Caffesse, R.G., Nissle, R.R. and Appleberry, E.A. : Effect of periodontal treatment on tooth mobility. J. Periodontol., 53 : 635-638, 1982

46）加藤 筥 : 歯の動摇度（上）一臨床的ならびに 基 礎的な歯周組織の力学的研究一. 歯界展望, 48 : 529-539, 1976.

47) O'Leary, T.J., Rudo, K.D. and Nabers, C.L. : Factors affecting horizontal tooth mobility. Periodontics, 4 : 308-315, 1966.

48) Wasserman, B.H., Geiger, A.M. and Turgeon, L.R. : Relationship of occlusion and periodontal disease Part VII-mobility. J. Periodontol., 44 : $572-578,1973$

49） 戸栗和慶, 向坂康彦, 山崎 修, 花田晃治, 山鹿 卓郎, 石岡 靖, 木竜 徹: 下顎前突者の被蓋改 善前後におりる咀嚼笳筋電図波形についての研 究. 日矯歯誌， $41 ： 244-259,1982$.

50）山鹿卓郎, 石岡 靖, 木竜 徹, 鈴木道斉, 斉 藤義明 : 筋電図の自動解析 第 3 報 Silent Period の認識について. 日補緅誌，26:526-531， 1982.

51）木竜 徹, 山鹿卓郎, 斉藤義明, 石岡 靖 : 筋 電図の自動解析 第 4 報 統計的波形分析による Silent Period 前後の咀嚼笳筋電図解析. 日補緅 誌, $26: 814-821,1982$

52) Widmalm, S.E. : The silent period in masseter muscle of patients with TMJ dysfunction. Acta Odont. Scand., $34: 43-52,1976$. 